\title{
CSTC T-PPR: ORGANIZATIONAL ACTIONS TO INCREASE POWER EFFICIENCY RECONSTRUCTION OF HISTORICAL BUILDINGS OF ODESA UNDER CHANGES
}

\author{
КНТК МЕРЕК: ОРГАНІЗАЦІЙНІ ЗАХОДИ ПІДВИЩЕННЯ \\ ЕНЕРГОЕФЕКТИВНОСТІ РЕКОНСТРУКЦІЇ БУДІВЕЛЬ \\ ІСТОРИЧНОЇ ЗАБУДОВИ ОДЕСИ ЗА ЗМІН
}

UDC 65.011.4:658.562:692.

https://doi.org/10.32843/infrastruct41-23

\section{Posternak Iryna}

Candidate of Technical Sciences,

Associate Professor,

Senior Lecturer at Department

of the Organization of Building

Odessa State Academy

of Civil Engineering and Architecture

Posternak Serhii

Candidate of Technical Sciences,

Associate Professor

Private Company "Composite"
Reconstruction of historical building has the big social and economic value. Its primary goals consist not only in service life extension of buildings, but also in liquidation of service wear, improvement housing conditions, equipage of residential buildings with the modern engineering equipment, increase of the operational characteristics and architectural expressiveness. It is offered to create "the Corporate scientific and technical complex town-planning power reconstruction "CSTC T-PPR" in the city of Odesa, as innovative organizational structure, which uses in practice the accumulated scientific and technical potential for reconstruction of historical buildings of Odesa under standards of power efficiency. The considered method of calculation the building stream M-CUR possesses positive property of an effective utilization of labor cost and machine resources, at their considerable (defining duration of works) costs; however, there are breaks in development of separate private fronts of works. Key words: an operational construction management; scheduling; the construction organization; a corporate scientific and technical complex; town-planning power reconstruction.

Реконструкция исторической застройки имеет большое социально-экономическое значение. Ее основные задачи состоят не только в продлении срока службы зданий, но и в ликвидации фризического и морального износа, улучшении условий проживания, оснащении жилых зданий современным инженерным оборудованием, повышении эксплуатационных характеристик и архитектурной выразительности. Предлагается создать в городе Одессе «Корпоративный научно-технический комплекс градостроительной энергореконструкции «КНТК ГЭРек», как инновационную организационную структуру, которая использует на практике накопленный научно-технический потенциал для реконструкции зданий исторической застройки Одессы по стандартам энергоэфрорективности. Рассмотренный метод расчета строительного потока метод непрерывного использования ресурСОв (М-НИР) обладает положительным свойством эфрфрективного использования стоимости трудовых и машинных ресурсов, при их значительной (определяющей продолжительность работ) стоимости. Однако при этом возникают перерывы в освоении отдельных частных фронтов работ.

Ключевые слова: оперативное управление строительством, календарное планирование, организация строительства; корпоративный научно-технический комплекс; градостроительная энергореконструкция.

У якості однієї з перспективних форм інтеграції виступають у містобудівній структурі різні комплекси. Тенденції економіки сучасного інсформаційного суспільства такі, що рушійною силою інноваційного розвитку суспільства стає наука. Розробка і впровадження нових і вдосконалення існуючих технологій в капітальному будівництві визначається необхідністю зниження матеріальних і трудових витрат на їх виконання, щорічні розміри яких обчислюються мільйонами гривень прямих витрат і мільйонами люд.-днів. трудових витрат, а також необхідністю скорочення інвестиційного чиклу будівництва будівель та споруд. Розширене відтворення вимагає подальшого підвищення рівня поділу праці, концентрації й спеціалізації будівельного виробництва, інтенсифікації обміну результатами виробничо-господарської діяльності. Реконструкція історичної забудови має велике соціально-економічне значення. їі основні завдання полягають не тільки в продовженні терміну служби будівель, але і в ліквідації фізичного і морального зносу, поліпшенні умов проживання, оснащенні житлових будинків сучасним інженерним обладнанням, підвищення експлуатаційних характеристик і архітектурної виразності. Пропонується створити у місті Одесі «Корпоративний науково-технічний комплекс містобудівної енергореконструкції «КНТК МЕРек», як інноваційну організаційну структуру, яка використовує на практиці накопичений науково-технічний потенціал для реконструкції будівель історичної забудови Одеси за стандартами енергоефрективності. При організації керування КНТК МЕРек не можна лише пристосовувати діючий господарський механізм, необхідний пошук нових форм і методів забезпечення координації в діяльності органів керування різних ланок. Потоковий метод організації робіт фоормується за допомогою просторового розподілу загального фрронту робіт на часткові фрронти робіт і паралельного виконання на них різнотипних часткових потоків робіт. Розглянутий метод розрахунку будівельного потоку - метод безперервного використання ресурсів (М-БВР) володіє позитивною властивістю ефрективного використання вартості трудових і машинних ресурсів, при їх значній (визначальна тривалість робіт) вартості. Однак при цьому виникають перерви в освоєнні окремих приватних фрронтів робіт.

Ключові слова: оперативне управління будівництвом; календарне планування; організація будівництва; корпоративний науково-технічний комплекс; містобудівна енергореконструкція.

Problem statement. As one of perspective forms of integration, various complexes act in townplanning structure; in the course of formation plans of social and economic development of large cities even more often there is a situation when financial, material and a manpower concentration of efforts are used to increase efficiency, as well as new progressive forms of the organization of building manufacture, such as corporate, scientific and technical, are necessary also with the power efficiency.
Review of last sources of researches and publications. World practice shows, that increase power efficiency is reached mostly at the expense of organizational changes in a guidance system power economy the enterprises or cities. Having introduced power management system, it is possible to reach considerable energy conservation in $3 . .5 \%$ for $1 . . .2$ years without the big financial losses. Power management includes a set of the actions aimed at economy power resources: monitoring power 
consumption, working out power budgets, analyzing of indicators as bases drawing up new budgets, working out a power policy, mapping out new power savings actions etc. Power efficiency building is about property of a building, its structural components and plumbing system during expected life cycle this building household requirements to provide the person with optimum microclimatic conditions for his/her stay in premises such building at is standard and admissible (optimum) expenses on power resources for heating, illumination, fanning, an air conditioning, heating of water taking into account a climatic conditions [1].

In town-planning the tendency to integration, both in sphere of production of goods, and in management sphere is shown; the expanded reproduction demands the further increase of the level of a labor division, concentration and specialization of building manufacture, an intensification exchange of results, which are the industrial and economic activities. Various complexes act in town-planning structure are as one of perspective forms of integration; in the course formation plans social and economic development of large cities even more often there is a situation when financial, material and a manpower concentration of efforts are used to increase efficiency, as well as new progressive forms of the organization of building manufacture, such as corporate, scientific and technical, are necessary also with the power efficiency [2-5].

Research objective. It is to offer the organizational structure using in practice the accumulated scientific and technical potential for reconstruction of historical building of Odessa of 1820...1920 under standards of power efficiency and execute research line method of the organization of works - a method of continuous use of resources (M-CUR).

The basic material and results of researches. The first samples of the joint-stock companies (and they were called as corporate) have appeared in days the Middle Ages. Cities had the right to self-management, with universities and monastic order. Their feature was that, having actives, they existed irrespective the members. In the 15th century in the Great Britain, which was known for existence of the system of the capable right, the English court has generated unique line of this organizational form: the limited liability principle became lawful, and in 1886 this norm was legally fixed in the USA.

Corporate forms of modern type appeared in 1850 at the railway industry and in 1880 in areas, which develop consumer goods.

In the 20th century there appeared new forms the organization of business, in particular holdings and financial and industrial groups.

The factor, which provided formation of the new forms of corporate business, was the increasing of the economic globalization. The globalization began as a scale of historical process and appeared in occurrence and development of the transnational corporations, which steeled almost the most effective and the most viable form of the organization of the general business and manufacture.

Formation of corporate sector in Ukraine was carried out mainly through privatization, i.e., transformation of the operating enterprises on joint-stock companies. The structure of such enterprises was far not optimum, in this connection they required reorganization.

Such activity was called the "restructuring"; it represented many-sided work, which concerned different aspects of the enterprises' activity. Nevertheless, in overwhelming majority of the cases restructuring was understood as the processes of downsizing the separate enterprises and formation of complete legal bodies of several subjects of managing with certain functions.

Organizational structures, which were formed on the basis of the former state enterprises, varied enough and depended on scales of manufacture, the purpose of development corporation of other powerful factors. Within the limits of corporation variety, the separate enterprises can function, and there can be, on the contrary, a rigid control system by a linearlystaff principle where acceptance level of all more or less important decisions becomes isolated on the first person. It is necessary to notice, that basically reorganization actions went on crushing the enterprises by creation separate legal bodies.

Feature of the Ukrainian integrated corporations was that they were generated on the basis of industrial complexes of the Soviet period as to disintegration of the USSR they had the highest level of branch integration whereas in the developed countries all big business functioned by a principle of interbranch integration, merge bank and industrial capitals. As a result, all Ukrainian corporate structures represented complete industrial chains, but had not complete structure of the financial block. Activity of the integrated corporate structures was described by instability of the property rights, as it was frequent when those rights, which were formally fixed, were the insufficient basis for realization by their owner.

Nowadays, the search of new forms of integration, which would give the chance to strengthen and order relations the property and industrial-financial relations, have passed. If to consider experience of the developed countries, it is possible to conclude that there is no structure, which would solve all these disagreements. At the same time, in the course of evolution holdings and multidivisional structures began to prevail as the forms of integration in the Western Europe and the USA. However, in each of these structures, constant search of an optimum parity and function of its part for the purpose to increase efficiency of activities of all integrated corporation has passed. 
The state (municipal) economic association is the association of the enterprises formed by the state (municipal) enterprises under the decision of the Cabinet of Ministers the Ukraine or in cases defined by the law by the decision of the ministries (other bodies, to which sphere management enters the enterprises, which form association), or under the decision of the competent local governments.

Associations can be formed as corporations, consortia, concerns, etc.

The corporation is the contractual association created on the basis of the industrial, scientific and commercial interests of the enterprises, which have united, having delegated separate powers and the centralized regulation activity each of participants to controls.

In work, the scheduling method in the organization of building manufacture is used. The planned schedule is such a design document, in which terms and costs performance works are displayed dynamically (i.e. in time). The planned schedule can be presented in various forms (descriptive, matrix, a sheetcalendar, graphic, etc.), from which the graphic form is the most evident. It is widely applied in the form of the linear schedule chart (Gantt chart) and the network schedule (count). In substantial aspect, the planned schedule is a system that unites technology, the organization and economy building manufacture. The planned schedules are the basis for both the organization building manufacture and the projects management. The planned schedules are developed as a part of following projects: the business plan the investment building project; the project organization of building; the project of a substantiation of investments; offers for the representation on the contract auctions; the project manufacture works; the project annual organization of works the building organization; technological cards, etc.

The planned schedule is also a basis for formation of the schedule of financing building and the schedule of a monetary stream, connected with an estimation of economic efficiency of the project.

The scheduling initial stage is connected with a choice of model the organization works, which to the greatest degree satisfies to requirements of manufacture, concrete economic and specifications. Depending on taking place, conditions of the organizational-technological scheme, which is a basis for working out of model the planned schedule, are defined. The Organizational-technological scheme mainly defines topological statement a problem scheduling, and also essential conditions, criteria and restrictions. Methods and ways of the organization works are defined by concrete conditions of building, character coordination of works in their technological sequence, in time and space. Creation of the organizational-technological scheme of building object is the difficult creative process demanding the expert with high qualification in the field scheduling building.
On the planned schedules the general elements take place. We will consider the cores from them:

Division of building space is into private fronts of works. The building space including either separate object, or group of objects, can be divided into separate private fronts of works depending on character of design decisions and possibilities consecutive performance works on the allocated private fronts. Allocation of the private fronts of works from the general building space is a necessary condition for the organization of building stream as which basic sign it is necessary to consider combination in time performance different kinds of works for different parts of object or a complex objects. It is necessary to notice, that the private front is the generalized name of the allocated part of building space.

Division of building is into private streams of works. Division building space into private fronts shows where works are performed. Unlike it, division of building into private streams defines what works should be performed. As top level of the hierarchy reflecting specialization of work in building, cycles of works can be allocated. In turn, cycles of works include separate kinds of works. According to hierarchy the work kind is followed by building processes, their result of performance is the intermediate release or final building production. Building processes can be simple and complex, i.e. including simple processes. Further simple processes are subdivided into working operations, invariant of which is the fixed cast, means and work tools. Manufacture of working operations is carried out by means of their decomposition on separate working receptions.

Kinds of works technological cards serve for the description of performance conditions, for the description of processes there are cards of labor processes. In some cases, these descriptions are supplemented with technological norms, which define all essential conditions and ways the control of works and the operations, necessary for their qualitative and effective performance.

As leading sign expediency application coordination principles of management the generality the economic purposes and the problems, demanding industrial cooperation, acts.

From positions of methodology management CSTC T-PPR is the economic object of the new class, which has received the name integration. Its specificity follows from its integrated approach that assumes:

-high level coincidence interests of the basic industrial organizations entering in CSTC T-PPR at preservation a branch accessory and its corresponding inclusiveness in branch systems of planning, financing, logistics and management.

-the interrelation of economic activities defining their dependence in achievement of both own and branch purposes, forming the given complex. 
-territorially caused social and economic unity is impossible without realization of the coordinated economic policy, free from administrative restrictions.

Such are the most general features, testifying that at the organization of management of CSTC T-PPR it is impossible to adapt only an operating economic mechanism, search of new forms and methods is necessary. In effect, the main problem today is maintenance of coordination in activity of the controls concerning various links and levels of the building branch. It is necessary more often to suggest them to unite "under the general roof". However, such structures are too bulky, unhandy, and are not always realized in practice, especially in building. It is necessary to organize thus participants of CSTC T-PPR that they, realizing own purposes, would reach also the general results - we will tell, with partners in building of those or other building objects or with accessory manufacturers, though and not participating directly in works, but providing them, etc. Such mechanism is coordination. Integrity of CSTC T-PPR is given by not so much spatial organization, how many that end result - a product of manufacture of reconstruction, which is created by builders. Now, when the emphasis becomes on economic control levers, neglect lessons coordination management in relation to primary economic cells are necessary for considering.

Before builders and architects there is an uneasy problem as reconstruction and the adaptation of such objects to new functions should be spent taking into account all requirements and specifications on protection an architectural heritage and having complex character taking into account prospects of development of the whole city, separate quarter and object. When carrying out reconstruction, it is extremely important to keep aesthetic and architectural qualities of historical buildings, especially their facades. Therefore, the big attention is necessary for reconstruction protecting designs.

For all protecting designs a building as a whole, first of all, it is necessary to develop the concept a thermal protection and to make the comprehensive list actions. It will help to make the decision concerning calculation parameters of a thermal protection, a choice the sizes and carrying out separate actions for a thermal protection. For each constructive element, there are many variants a thermal protection, and our problem is to choose the most practical of them. At decision-making, the estimation is made by following criteria: power efficiency and the importance within the limits of all complex actions for reconstruction; practicability with reference to an available building and risks of by-effects; improvement thermal characteristics, increase comfort and improvement appearance a building; cost and an estimation as a group received improvement of the quality.

Development of the concepts of a thermal protection for designing a building is not less important than the list of wishes or exceptions at a choice thermal protection material. It is important, because at use of the ecologically pure materials the maximum values can be reached only at higher expenses for designing, the big attention to details and as a group to higher cost of all works.

Before the beginning planning power reconstruction, it is necessary to define quantity of power consumption to which it is necessary to aspire. In an original form, it is recommended to stop on an intermediate variant somewhere in between the improved building and "the passive house". Exact values will be defined within the limits of the further planning. It is possible to choose both maximum and minimum thickness of isolation. The matter is that in parallel with thermal protection measures on decrease in consumption energy, including on hot water supply, other measures are planned for economic-household installations, the equipment, and other needs. The principle question demanding the answer is the following: what expenses are demanded by realization this or that measure, and what economy energy it will allow to achieve?

Not for all historical building it is possible to achieve an optimum thermal protection, having kept in frameworks adequate expenses. For example, restrictions can be imposed by an available design or the legislation on protection an architectural heritage. It is possible to compensate these restrictions for the account of use the improved heating system that will allow lower the expense primary energy considerably. It is very important at the earliest stages planning to consider all accessible introduction power savings technologies and compare them taking into account their cost received at their expense economy and decrease emissions of $\mathrm{CO}_{2}$. Here frequently it is required to apply non-standard, and even the creative approach.

The estimation of a share flat surfaces various constructive elements protecting designs a building (wall/roof/basement overlapping/window) for buildings various types shows considerable distinctions. Therefore, at estimation variants a thermal protection is necessary to make both quantitative and qualitative estimations, placing priorities in appropriate way.

There are such constructive elements buildings, for which thermal protection perfection is not unique or at least a reconstruction main objective. Some constructive elements building and without that require improvement, replacement or reconstruction, for example, the decayed window covers, not tight or even the proceeding roof, the peeled off plaster on a facade concern. In such cases an expense for power reconstruction are inevitable, because not only functionality of a building and its suitability for residing suffer, but also building aesthetics, and elimination of these lacks any case will demand financial expenses.

Line methods of the organization works can be calculated in the different ways, therefore they have received names of methods calculation the 
organization works. We will consider a method of continuous use of resources (M-CUR).

For calculation formation streams on method M-CUR we will consider the line organization of works presented by matrix durations and the schedule internal painting and decorating, at reconstruction buildings of historical building of Odesa under standards power efficiency (tab. 1).

On four building objects (historical building of Odessa), defined as private fronts of works, are carried out four kinds of works in rigid technological sequence $(A \rightarrow B \rightarrow C \rightarrow D)$ on each object: plaster works (index $A$ ), priming works (index $B$ ), under paint putty works (index $\mathrm{C}$ ) and works on colorings (index D). The sequence development private fronts works is also fixed by the following sequence: $1 \rightarrow 2 \rightarrow 3 \rightarrow 4$.

Each kind of work is carried out by constant cast, which passes to the following object only after the full termination work on previous object. If the given complex works is carried out by a consecutive method its minimum duration will be equal to the sum of durations of all works entering into a given complex:

$$
\begin{gathered}
T=7+9+6+8+2+3+2+3+13+17+ \\
+11+15+5+8+4+6=119 \text { days. }
\end{gathered}
$$

For the line organization works at performance any work on any object performance two obligatory conditions are required:

1) the termination of the given kind of work a resource on previous object (resource readiness of executors);

2) the termination of a previous kind of work on the given object (technological readiness of the private front of work).
In the centre of each element tab. 1 shows values duration works in days. At formation of schedules works the primary goal consists in calculation terms manufacture works or, otherwise, terms the beginnings and the terminations works.

For the given stream (tab. 1) as restriction maintenance of continuous performance of each kind of work (a zero stretching of resource communications), and as criterion function - the greatest possible rapprochement of adjacent kinds of works (private streams) is entered.

For a conclusion of the basic settlement formulas the size carrying the name of the period expansion, which defines a difference between the beginning of the subsequent work on private front I and the beginning of previous work on the same front $-T^{w}{ }_{i+1}$, is entered into consideration. Clearly, the first work in a technological order is not preceded by any other work and its beginning is accepted by zero. Thus, having defined the beginning of the first work and the corresponding period of expansion of the second work, it is possible to calculate the beginning of its manufacture on private front I etc. (on an induction) before definition of the beginning last kind of work.

Having calculated the beginning of last work taking into account restriction on continuity of performance works, it is possible to define the general duration all complex of works under the formula (1):

$$
T=\sum_{i=1}^{m-1} T_{i+1}^{w}+\sum_{j=1}^{n} t_{m, j},
$$

where $T^{w}{ }_{i+1}$ - the period of expansion of the subsequent work; $m$ - the general number of kinds of works

Matrix durations and the schedule internal painting and decorating,

\begin{tabular}{|c|c|c|c|c|c|}
\hline \multirow{2}{*}{$\begin{array}{l}\text { Index and the name } \\
\text { of works }\end{array}$} & \multicolumn{4}{|c|}{ Private front of work } & \multirow{2}{*}{ Total duration of work } \\
\hline & $\mathbf{I}$ & II & III & IV & \\
\hline A. Plaster works & $\begin{array}{l}0 \\
7\end{array}$ & $\begin{array}{l}7 \\
9\end{array}$ & 16 & $\begin{array}{l}22 \\
\quad 8\end{array}$ & $30=7+9+6+8$ \\
\hline B. Priming works & 25 & 28 & 2 & 3 & $\begin{array}{c}T_{B}{ }^{w}=23 \\
10=2+3+2+3\end{array}$ \\
\hline $\begin{array}{l}\text { C. Under paint putty } \\
\text { works }\end{array}$ & $\begin{array}{lll}25 & & 38 \\
& \underline{13} & \end{array}$ & $\begin{array}{ll} & 55 \\
17 & \end{array}$ & $\begin{array}{ll} & 66 \\
11 & \end{array}$ & $\underline{15}$ & $\begin{array}{c}T_{C}^{w}=2 \\
56=13+17+11+15\end{array}$ \\
\hline D. Works on coloring & $\begin{array}{lll}64 & & 69 \\
& 5 & \end{array}$ & $\begin{array}{ll} & 77 \\
8\end{array}$ & $\begin{array}{l}81 \\
4\end{array}$ & $\begin{array}{ll} & 87 \\
\underline{6} & \end{array}$ & $\begin{array}{c}T_{D}^{w}=39 \\
23=5+8+4+6\end{array}$ \\
\hline $\begin{array}{c}\text { Total durations of fronts } \\
\text { of works }\end{array}$ & $\begin{array}{c}69=69-0 \\
27= \\
7+2+13+5 \\
42=69-27\end{array}$ & $\begin{array}{c}70=77-7 \\
37= \\
9+3+17+8 \\
33=70-37\end{array}$ & $\begin{array}{c}65=81-16 \\
23= \\
6+2+11+4 \\
42=65-23\end{array}$ & $\begin{array}{c}65=87-22 \\
32= \\
8+3+15+6 \\
33=65-32\end{array}$ & $\begin{array}{c}\text { Stretching } \\
\text { of communications } \\
\text { frontal - } 150\end{array}$ \\
\hline
\end{tabular}
at reconstruction of historical building of Odesa under standards of power efficiency, calculated by a method of continuous use of resources

Source: developed by authors on the basis of scheduling 
(a current serial index, $i$ ); $n$ - the general number of he fronts works (a current serial index, $j$ ); $t_{m, j}$ - duration of last kind work on $j$-th front.

For definition of values the periods of expansion subsequent works we will take advantage of a condition (2) at which prior to the beginning of any simple work previous work by the form on the same private front should be executed:

$$
T_{i+1}^{w}=\max _{j=1, n} \sum_{k=1}^{j}\left(t_{i, k}-t_{i+1, k-1}\right),
$$

where $t_{i+1,0}-$ operation time on zero front is equal to zero.

Let us take advantage of the previous formula (2) and define the periods expansion works $B, C$ and $D$, shown by following formulas (3):

$$
\begin{aligned}
& T_{B}^{w}=\max \left\{\begin{array}{l}
7-0=7 \\
7+9-0-2=14 \\
7+9+6-0-2-3=17 \\
7+9+6+8-0-2-3-2=23
\end{array}\right] \\
& T_{C}^{w}=\max \left\{\begin{array}{l}
2-0=2 \\
2+3-0-13=-8 \\
2+3+2-0-13-17=-23 \\
2+3+2+3-0-13-17-11=-31
\end{array}\right\}=23 \\
& T_{D}^{w}=\max \left\{\begin{array}{l}
13-0=13 \\
13+17-0-5=25 \\
13+17+11-0-5-8=28 \\
13+17+11+15-0-5-8-4=39
\end{array}\right\}=2 ;
\end{aligned}
$$

Conclusions and scientific novelty. Therefore, reconstruction of historical building has the big social and economic value. Its primary goals consist not only in in service life extension of buildings, but also in liquidation of service wear, improvement housing conditions, equipage of residential buildings with the modern engineering equipment, increase of the operational characteristics and architectural expressiveness. It is offered to create "the Corporate scientific and technical complex town-planning power reconstruction "CSTC T-PPR" in the city of Odesa, as innovative organizational structure, which uses in practice the accumulated scientific and technical potential for reconstruction of historical buildings of Odesa under standards of power efficiency. The considered method of calculation the building stream M-CUR possesses positive property of an effective utilization of labor cost and machine resources, at their considerable (defining duration of works) costs; however, there are breaks in development of separate private fronts of works.

\section{REFERENCES:}

1. Asotsiatsiia enerhoaudytoriv Ukrainy. [Energy Auditors Association]. Available at: http://aea.org.ua/ru/ energy-management/ (accessed 5 March 2020).

2. Dzhedzhula, V. V. (2014). Enerhozberezhennia promyslovykh pidpryiemstv: metodolohiia formuvannia, mekhanizm upravlinnia [Energy saving industrial enterprises: Methodology of formation, management mechanism]. Vinnytsia: VNTU. (in Ukrainian)

3. Posternak I. M., Posternak S. A. (2016). Corporate scientific and technical complex town-planning power reconstruction "CSTC T-PPR" Odessa. The development of international competitiveness: state, region, enterprise: materials of the International scientific conference. Lisbon, Portugal: Baltija publishing. Part II. V. 1. Business economics and corporate management: innovation problem. pp. 6-8.

4. Posternak I. M., Posternak S. A. Die kalenderplanung bei der organisation des baues des komplexes städtebaulich energetisch-rekonstruktion. Economy and society: a modern foundation for human development: materials of the II International scientific conference, Germany, Leipzig, June 23th, 2017; Leipzig university: Baltija publishing, 2017. Part II. P. 44-47.

5. Posternak, I. M., \& Posternak, S. A. (2016). Sohranenie ob'ektov kulturnogo naslediya Odessyi s uchetom energomenedzhmenta [Preservation objects a cultural heritage of Odessa with the account power management]. Preservation of historic buildings in the central part of Odessa via inscribing in the UNESCO world heritage list (pp. 220-223). Odessa: Astroprint (in Russian).

\section{БІБЛІОГРАФІЧНИЙ СПИСОК:}

1. Асоціація енергоаудиторів України. URL: http://aea.org.ua (дата звернення: 05.03.2020).

2. Джеджула В.В. Енергозбереження промислових підприємств: методологія фрормування, механізм управління: монографрія / В.В. Джеджула. Вінниця: BНTУ, 2014. - 346 c.

3. Posternak I. M., Posternak S. A. Corporate scientific and technical complex town-planning power reconstruction "CSTC T-PPR" Odessa. The development of international competitiveness: state, region, enterprise: materials of the International scientific conference, Portugal, Lisbon, December 16, 2016; Nova university and Nova school of business and economics. Baltija publishing, 2016. Part II. Volume 1. Business economics and corporate management: innovation problem. P. 6-8.

4. Posternak I. M., Posternak S. A. Die kalenderplanung bei der organisation des baues des komplexes städtebaulich energetisch-rekonstruktion. Economy and society: a modern foundation for human development: materials of the II International scientific conference, Germany, Leipzig, June 23th, 2017; Leipzig university: Faculty of economics and management science. Baltija publishing, 2017. Part II. P. 44-47.

5. Постернак И. М., Постернак С. А. Сохранение объектов культурного наследия Одессы с учетом энергоменеджмента. Збереження історичної забудови чентра Одеси шляхом включення до основного списку Всесвітньої спадщини ЮНЕСКО $=$ Preservation of historic buildings in the central part of Odessa via inscribing in the UNESCO world heritage list: матеріали III і IV Міжнародних науковопрактичних конференцій, м. Одеса, 2-4 грудня 2015 р. та 15-16 грудня 2016 р., Одеса: Астропринт, 2016. C. $220-223$. 